\title{
PENGARUH MODEL PEMBELAJARAN THINK PAIR SHARE (TPS) TERHADAP KEMAMPUAN KOMUNIKASI MATEMATIKA SISWA KELAS X SMA MELATI BINJAI TAHUN PELAJARAN 2019/2020
}

\author{
Riska Febriani br. Sembiring ${ }^{1)}$, R. Maisyaroh Siregar ${ }^{2)}$ \\ Mahasiswa STKIP Budidaya Binjai ${ }^{1}$, Dosen STKIP Budidaya Binjai ${ }^{2}$ \\ e-mail : riskafebrianibrsembiring@gmail.come-mail : maisaroh@gmail.com
}

\begin{abstract}
ABSTRAK
Penelitian ini bertujuan untuk mengetahui apakah terdapat pengaruh model pembelajaran think pair share(TPS) terhadap kemampuan komunikasi matematika siswa kelas X SMA MELATI BINJAI Tahun Pelajaran 2019/ 2020. Penelitian ini dilaksanakan di SMA Melati Binjai pada semester ganjil, tahun pelajaran 2019/2020. Populasi dalam penelitian ini adalah seluruh siswa kelas X SMA Melati Binjai sebanyak 5 kelas, dengan jumlah seluruh populasinya adalah 140 siswa.Sampel dalam penelitian ini adalah kelas X- Mia 3 yang berjumlah 30 siswa. Jenis penelitian ini merupakan penelitian desain pre-experimental. Desain penelitian atau rancangan penelitian dalam penelitian ini adalah desain pretes-pascates satu kelompok (one group pretest-postest design). Instrumen yang digunakan untuk mengumpulkan data adalah tes.Secara spesifik dapat disimpulkan bahwa rata-rata kemampuan komunikasi matematika siswa kelas $\mathrm{X}$ SMA Melati Binjai sebelum diterapkannya model pembelajaran think pair share(TPS) hanya sebesar 52,33. Rata-rata kemampuan komunikasi matematika siswa kelas X SMA Melati Binjai setelah diterapkannya model pembelajaran think pair share(TPS) meningkat dari 52,33 menjadi 72,50. Dapat diambil kesimpulan bahwa terdapat pengaruh model pembelajaran think pair share(TPS) terhadap kemampuan komunikasi matematika siswa kelas X SMA Melati Binjai Tahun Pelajaran 2019/ 2020.
\end{abstract}

Kata Kunci :Think Pair Share(TPS), Kemampuan Komunikasi Matematika

\section{PENDAHULUAN}

Mengamati pendidikan di Indonesia, kita akan mendapatkan beberapa fenomena dan indikasi yang sangat tidak kondusif untuk mewujudkan Indonesia menjadi negara maju dalam bidang pendidikan (Hamdani, 2011:5). Indonesia adalah negara berkembang, sehingga membutuhkan beberapa faktor agar dapat menjadi negara maju.Beberapa faktor yang dibutuhkan untuk mengembangkan negara menjadi negara yang maju yaitu sumber kekayaan alam dan sumber daya manusia. Namun sumber kekayaan alam tidak akan bergunatanpa ditunjang dari kualitas sumber daya manusianya sendiri. Berdasarkan halter tersebut Indonesia sebagai negara berkembang harus meningkatkan kualitas sumber daya manusianya. Salah satu cara untuk meningkatkan sumber daya manusia Indonesia adalah dengan cara meningkatkan kualitas pendidikan di Indonesia.

Undang-Undang Republik Indonesia Nomor 20 tahun 2003 tentang Sistem Pendidikan Nasional disebutkan bahwa pendidikan adalah usaha sadar dan terencana untuk mewujudkan suasana belajar dan proses pembelajaran agar siswa secara aktif mengembangkan potensi dirinya untuk 
memiliki

kekuatan

spiritual

keagamaan,pengendalian diri, keperibadian, kecerdasan, akhlak mulia, serta keterampilan yang diperlukan dirinya, masyarakat, bangsa, dan negara (Depdiknas, 2009:5).

Guru sangat berperan penting dalam perbaikan mutu pendidikan karena guru akan menciptakan siswa yang berkualitas. melalui pembelajaran.Proses pembelajaran merupakan langkah kegiatan yang dilakukan oleh guru terhadap siswa dan sangat mempengaruhi perkembangan siswa. Jika proses pembelajaran berjalan dengan baik maka siswa akan merasa nyaman dan aktif selama proses pembelajaran. Sebaliknya, jika proses pembelajaran yang monotonmaka cenderung membuat siswa menjadi bosan dan pasif. Oleh karena itu,proses pembelajaran perlu dilakukan secara optimal pada semua mata pelajaran,termasuk dalam pembelajaran matematika.

Pentingnya pembelajaran matematika sebagai bagian dari proses pendidikan diatur oleh pemerintah. Pemerintah melalui Badan Standar Nasional Pendidikan menyatakan bahwa mata pelajaran matematika perlu diberikan kepada semua peserta didik mulai dari sekolah dasar untuk membekali peserta didik dengan kemampuan berpikir logis, analitis, sistematis, kritis, dan kreatif, serta kemampuan bekerjasama (BPNP, 2006:345).

Matematika bukan hanya sekedar alat bagi ilmu, tetapi lebih dari itu matematika adalah bahasa.Sejalan dengan itu Suriasumantri menyatakan, matematika merupakan bahasa yang melambangkan serangkai makna dari pernyataan yang ingin kita sampaikan.

Matematika selalu digunakan dalam segi kehidupan, merupakan saranan komunikasi yang kuat, singkat, dan jelas serta dapat digunakan untuk menyajikan informasi dalam berbagai cara (Rahman dkk, 2016:14). National Council of Teacher Mathematics (NCTM) dalam (Saragih, 2016:7) mengatakanbahwa komunikasi matematik adalah kemampuan siswa dalam :

1) Membaca dan menulis matematika dan mentafsirkan makna dan ide dari tulisan.

2) Mengungkapkan dan menjelaskan pemikiran mereka tentang ide matematika dan hubungannya.
3) Merumuskan definisi matematika dan membuat generalisasi yang ditemui melalui investigasi.

4) Menulis sajian matematika dengan pengertian.

5) Menggunakan kosakata/bahasa, notasi struktur secara matematika untuk menyajikan ide menggambarkan hubungan, dan pembuatan model.

6) Memahami, menafsirkan dan menilai ide yang disajikan secara lisan, dalam tulisan, atau dalam bentuk visual.

7) Mengamati dan membuat dugaan, merumuskan pertanyaan, mengumpulkan dan menilai informasi, dan menghasilkan dan menyajikan argumen yang meyakinkan.

Menyadari akan pentingnya kemampuan komunikasi matematika bagi siswa, maka guru harus mengupayakan pembelajaran dengan menggunakan pendekatan, metode atau model pembelajaran yang dapat melatih serta mendorong kemampuan komunikasi matematika siswa. Dalam pembelajaran matematika kemampuan berpikir tingkat tinggi, rasa ingin tahu yang tinggi, dan kreatif merupakan kemampuan yang perlu dimiliki oleh siswa.Dengan kemampuan komunikasi matematika, siswa dapat memperoleh pengetahuan, mengungkapkan ide-ide yang mereka miliki atau mengekspresikan konsepkonsep yang dimilikinya untuk menyelesaikan suatu masalah matematika sehingga guru mampu mengetahui ketidak pahaman siswa mengenai suatu materi yang diajarkan.

Meskipun kemampuan komunikasi matematika merupakan salah satu kemampuan yang harus dimiliki oleh siswa, namun kenyataan di lapangan masih banyak siswa yang belum terampil dalam bidang matematika yang berkaitan dengan kemampuan komunikasi.Rendahnya kemampuan komunikasi matematika siswa tentunya disebabkan oleh banyak faktor. Salah satu faktor dalam hal ini disebabkan siswa tidak dibiasakan dalam mengemukakan pendapat/gagasan/ide dalam pembelajaran di sekolah, padahal siswa yang mampu mengomunikasikan idenya baik secara lisan atau tulisan, akan lebih banyak menemukan cara penyelesaian suatu permasalahan. Salah satu faktor yang mempengaruhi keberhasilan 
belajar mengajar adalah pandangan guru terhadap siswa. (Fathurrohman, 2007:115) menyatakan dalam bukunya bahwa Guru yang memandang anak sebagai makhluk individual yang tidak memiliki kemampuan atau laksana kertas kosong akan banyak menggunakan metode yang teacher-centered. Guru lebih terfokus untuk mengeja rmateri agar selesai tepat waktu dan memberikan contoh-contoh soal yang sekiranya akan muncul pada ujian. Pembelajaran yang biasa digunakan dengan tujuan seperti itu adalah pembelajaran konvensional. Pembelajaran konvensional dalam hal ini adalah pembelajaran yang masih berpusat pada guru (teacher-centered) yang dilakukan dengan perpaduan metode ceramah, tanya jawab, dan penugasan.

Berdasarkan hasil observasi awal yang telah dilakukan di kelas X SMA Melati Binjai dengan salah satu guru bidang studi matematika yaitu bapak Arif Mandana,S.Pd pada hari Selasa 03 april 2019 dengan contoh soal seperti :Pada segitiga siku-siku diketahui panjang sisi miring lima kali panjang sisi alasdan kurang $5 \mathrm{~cm}$ dari jumlah sisi lainnya. Carilah panjang ketiga sisi-sisi segitiga jika keliling segitiga tersebut $55 \mathrm{~cm}$ !

Berikut ini adalah salah satu jawaban siswa dari soal di atas:

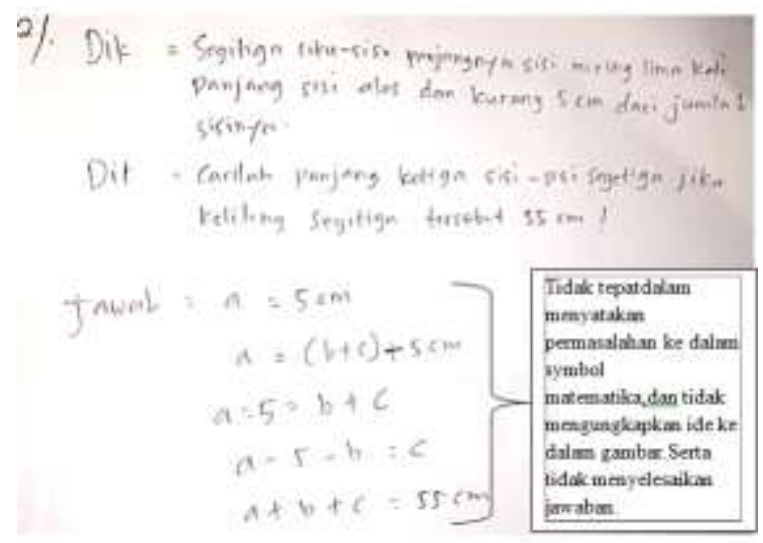

Gambar 1. Hasil Tes Awal

Pada indikator matematika dalam menjelaskan ide matematika secara tulisan dengan gambar dan aljabar serta menyertakan peristiwa sehari-hari dalam bahasa atau symbol masih rendah dari 25 siswa hanya 4 siswa yang mendapat nilai diatas 75 dan 21 siswa mendapat nilai dibawah 60. Berdasarkan hasil wawancara dengan guru bidang studi matematika di SMA Melati Binjai yaitu bapak Arif Mandana,S.Pd menyatakan bahwa siswa mengalami kesulitan dalam menyelesaikan soal-soal matematika dalam bentuk verbal, simbol maupun gambar. Selain itu, diketahui rata-rata nilai ulangan harian yang memuat soal kemampuan komunikasi matematika siswa sebesar 60.Nilai ini masih di bawah nilai Kriteria Ketuntasan Minimal (KKM) yaitu sebesar 75.Hal tersebut menjadi indikator Siswa bahwa kemampuan komunikasi matematika siswa di SMA Melati masih rendah. Untuk menyikapi masalah-masalah tersebut, maka diperlukan upaya untuk memperbaiki dan mengasah kemampuan komunikasi matematika siswa, salah satu cara yang dapat ditempuh adalah dengan menerapkan model pembelajaran Think Pair Share (TPS). Pembelajaran ini dapat membantu siswa menyampaikan ide-ide mereka secara mandiri yang kemudian didiskusikan bersama pasangan (teman sebangku) dan mempersentasikan hasil kepada teman sekelasnya.

Model pembelajaran kooperatif tipe Think Pair Share dapat membantu siswa untuk lebih aktif dan kreatif dalam pembelajaran berlangsung secara kelompok.Model pembelajaran Think Pair Share (TPS) dikembangkan oleh Frank Lyman dkk dari Universitas Maryland pada tahun 1985. Model pembelajaran Think Pair Share (TPS) merupakan salah satu model pembelajaran kooperatif sederhana. Teknik ini memberi kesempatan pada siswa untuk bekerja sendiri serta bekerja sama dengan orang lain. Anita Lie dalam (Nurjaman, 2015:2) mengemukakan bahwa keunggulan teknik ini adalah optimalisasi partisipasi siswa. Sehingga dalam penelitian Adi Nurjaman diperoleh hasil penelitian bahwa terdapat pencapaian dan kemampuan komunikasi matematik siswa yang pembelajarannya menggunakan model kooperatif tipe TPS lebih baik daripada siswa yang pembelajarannya menggunakan cara biasa. Model pembelajaran Think Pair Share (TPS) adalah salah satu model pembelajaran yang memberi kesempatan kepada setiap siswa untuk menunjukkan partisipasi kepada orang lain.

Anita Lie dalam (Nurjaman,2015:3) mengemukakan bahwa model pembelajaran Think Pair Share (TPS) ini memberi kesempatan sedikitnya delapan kali lebih 
banyak kepada siswa untuk dikenali dan menunjukkan partisipasi mereka kepada orang lain.

Berdasarkan uraian tersebut, peneliti terdorong untuk melakukan penelitian yang berjudul "Pengaruh Model Pembelajaran Think Pair Share (TPS) Terhadap Kemampuan Komunikasi Matematika Siswa Kelas X SMA Melati Binjai Tahun Pelajaran 2019/2020”.

\section{METODOLOGI PENELITIAN}

Penelitian ini dilaksanakan di SMA Melati Binjai. Waktu penelitian akan dilaksanakan pada semester ganjil, tahun pelajaran 2019/2020.

Populasi dalam penelitian ini adalah seluruh siswa kelas X SMA Melati Binjai Tahun Pelajaran 2019/2020 sebanyak 5 kelas, dengan jumlah seluruh populasinya adalah 140 siswa.Sampel dalam penelitian ini adalah kelas X- Mia 3 SMA Melati Binjai Tahun pelajaran 2019/2020 yang berjumlah 30 siswa.Dalam penelitian ini penulis menggunakan dua variabel yakni variabel bebas $(\mathrm{X})$ yaitu model pembelajaran Think Pair Share (TPS) dan variabel terikat (Y) yaitu kemampuan komunikasi matematika.Jenis penelitian ini merupakan penelitian desain pre-experimental. Desain penelitian atau rancangan penelitian dalam penelitian ini adalah desain pretespascates satu kelompok (one group pretestpostest design) yang merupakan bagian dari penelitian eksperimental semu.Instrumen yang digunakan untuk mengumpulkan data adalah tes.

\section{HASIL PENELITIAN DAN PEMBAHASAN}

Pada bagian ini akan dijelaskan tentang hasil sebelum dan sesudah pelaksanaan model pembelajaran think pair share(TPS) terhadap materi sistem persamaan linear tiga variabel untuk meningkatan kemampuan komunikasi matematika siswa kelas X SMA Melati Binjai tahun pelajaran 2019/2020.

\section{Analisis Deskriptif Kemampuan Komunikasi Matematika Siswa}

Berdasarkan tujuan penelitian yang telah ditetapkan yaitu untuk mengetahui apakah terdapat pengaruh model pembelajaran think pair share(TPS) terhadap kemampuan komunikasi matematika siswa kelas X SMA Melati Binjai tahun pelajaran 2019/2020 sebelum dan sesudah mengikuti proses pembelajaran menggunakan model pembelajaran think pair share(TPS), maka pada bagian ini akan dipaparkan hasil perhitungan pretest dan postest terhadap 30 siswa kelas X -Mia 3 tahun pelajaran 2019/ 2020.

Berikut hasil perhitungan atau analisis data pretest dan postest terhadap 127 siswa dari instrumen tes berupa pretest dan postest yang telah mereka kerjakan sebelum dan sesudah mengikuti proses pembelajaran menggunakan model pembelajaran think pair share(TPS)

Tabel 1.Hasil Analisis Pretest Dan Postest Kemampuan Komunikasi Matematika

\begin{tabular}{cccccc}
\hline Data & N & $\begin{array}{c}\text { Minim } \\
\text { um }\end{array}$ & $\begin{array}{c}\text { Maxim } \\
\text { um }\end{array}$ & Mean & $\begin{array}{c}\text { Std. } \\
\text { Deviation }\end{array}$ \\
\hline Pretest & 30 & 25 & 80 & 52,33 & 13,94 \\
\hline Postest & 30 & 50 & 95 & 72,50 & 12,71 \\
\hline
\end{tabular}

Berdasarkan tabel 4.1 di atas tampak jelas bahwa pada hasil pretest kelas eksperimen 1 diketahui nilai minimum, nilai maksimum, dan rata-rata dan standar deviasi berturut-turut adalah 25, 80, 52,33 dan 13,94. Pada hasil postest kelas eksperimen 1 diketahui nilai minimum, nilai maksimum, rata-rata dan standar deviasi berturut-turut adalah 50, 95, 72,50 dan 12,71. Berikut ini akan ditampilkan histogram dari tabel 4.1 di atas : 


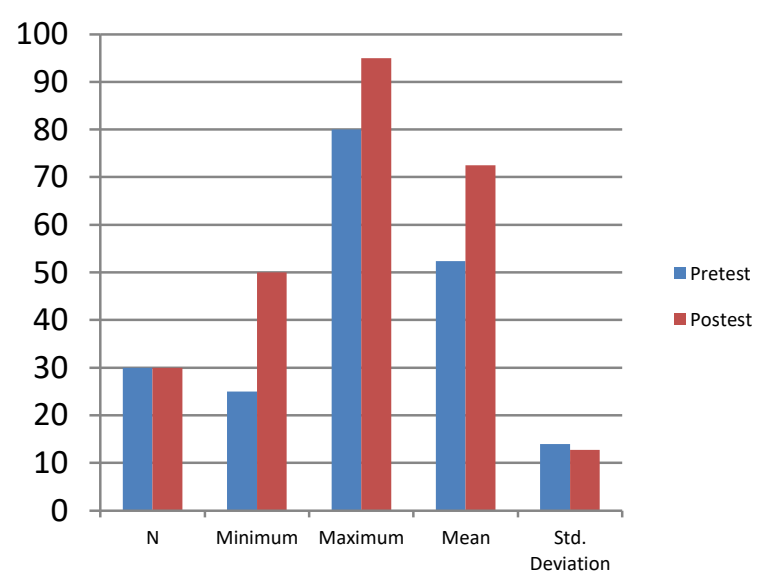

Gambar 2.Hasil Analisis Pretest Dan Postest Kemampuan Komunikasi Matematika

\section{Hasil Uji Normalitas}

Uji normalitas berguna untuk mengetahui data yang telah dikumpulkan (pretest dan postest) berdistribusi normal atau tidak dari suatu populasi atau sampel, jika data yang diperoleh berdistribusi normal berarti populasi atau sampel merupakan populasi atau sampel normal. Berkut tabel 4.3 hasil uji normalitas data data pretest dan postest.

Tabel 2.Hasil Uji Normalitas Data Pretest Dan Postest

\begin{tabular}{cccc}
\hline Data & $\begin{array}{c}\text { Asymp. Sig. } \\
\text { (2-tailed) }\end{array}$ & $\begin{array}{c}\text { Kriteria } \\
\text { Pengujian }\end{array}$ & Ket \\
\hline Pretest & 0,190 & $($ Sig. $)>0,05$ & Normal \\
\hline Postest & 0,208 & (Sig.) $>0,05$ & Normal \\
\hline
\end{tabular}

Berdasarkan kriteria pengujian uji normalitas maka diketahui penyebaran angket (pretest dan postest) sampel penelitian berdistribusi normal dengan keterangan nilai signifikansi (sig.) untuk pretest sebesar 0,190, dimana nilai ini lebih besar dari 0,05 artinya penyebaran pretest pada sampel penelitian berdistribusi normal dan untuk postest sebesar 0,208 dimana nilai juga ini lebih besar dari 0,05 artinya penyebaran postest pada sampel penelitian juga berdistribusi normal.

\section{Hasil Uji Regresi Linear Sederhana}

Regresi linear sederhana adalah metode statistik yang berfungsi untuk menguji sejauh mana hubungan sebab akibat antara Variabel Faktor Penyebab (X) terhadap Variabel Akibatnya (Y).Regresi linear sederhana juga dapat dipergunakan dalam produksi untuk melakukan peramalan ataupun prediksi tentang karakteristik kualitas maupun kuantitas. Faktor penyebab dalam penelitian ini adalah model pembelajaran think pair share (TPS) disebut juga dengan predictor sedangkan variabel akibat dalam penelitian ini adalah kemampuan komunikasi matematika disebut juga dengan response.Berikut hasil uji regresi linear sederhana. 
Tabel 3.Hasil Uji Regresi Linear Sederhana

\begin{tabular}{|c|c|c|c|c|c|}
\hline & \multirow[t]{2}{*}{ Model } & \multicolumn{2}{|c|}{$\begin{array}{l}\text { Unstandardized } \\
\text { Coefficients }\end{array}$} & $\begin{array}{l}\text { Standardi } \\
\text { zed } \\
\text { Coefficie } \\
\text { nts }\end{array}$ & \multirow[t]{2}{*}{ Sig. } \\
\hline & & B & $\begin{array}{l}\text { Std. } \\
\text { Error }\end{array}$ & Beta & \\
\hline \multirow[t]{2}{*}{1} & (Constant) & 47.880 & 2.600 & & $\begin{array}{r}18.41 \\
3\end{array} .000$ \\
\hline & Pretest & .798 & .064 & .934 & $\begin{array}{r}12.49 \\
6\end{array} .000$ \\
\hline
\end{tabular}

a. Dependent Variable: Postest

Berdasarkan tabel 4.3 di atas diperoleh nilai signifikansi (sig.) $0,000<0,05$, maka model regresi dapat dipakai untuk memprediksi variabel terikat (variabel Y). Pada kolom B baris constant didapat nilai 47,88 dan pada kolom B baris pretes didapat nilai 0,79 . Sehingga dari nilai-nilai tersebut dapat dibentuk sebuah persamaan regresi linear yaitu $Y=47,88+0,79 X$. Konstanta (a) sebesar 47,88 menunjukkan bahwa ketika variable independent model pembelajaran think pair share (TPS) konstan, maka rata-rata kemampuan komunikasi matematika sebsar 47,88. Koefisien regresi model pembelajaran think pair share (TPS) sebesar 0,79, menunjukkan bahwa setiap kenaikan 1 konstanta pada variabel model pembelajaran think pair share (TPS) terhadap kemampuan komunikasi matematika siswa sebesar 0,79 .Koefisien regresi bernilai positif menunjukkan bahwa semakin baik penerapan model pembelajaran think pair share (TPS, maka semakin baik pula kemampuan komunikasi matematika siswa.

\section{Hasil Uji Hipotesis}

Teknik untuk pengujian hipotesis adalah dengan uji-t menggunakan software aplikasi komputer SPSS 16. Pengambilan keputusan pengujian hipotesis didasarkan pada ketentuan sebagai berikut: $t_{\text {hitung }}>t_{\text {tabel }}$, maka Ho ditolak dan Ha diterima, jika $t_{\text {hitung }}<t_{\text {tabel }}$, maka Ho diterima dan Ha ditolak dengan taraf signifikansi 5\%. Berikut ini tabel 4.3 hasil uji hipotesis.
Tabel 4.Hasil Uji Hipotesis Paired Samples Test

\begin{tabular}{lcccccc}
\hline \multicolumn{5}{c}{ Paired Samples Test } \\
\hline & \multicolumn{4}{c}{ Paired Differences } & & \\
\cline { 2 - 4 } & $\begin{array}{c}\text { Std. } \\
\text { Mean } \\
\text { Deviati } \\
\text { on }\end{array}$ & $\begin{array}{c}\text { Std. } \\
\text { Error } \\
\text { Mean }\end{array}$ & $T$ & df $\begin{array}{c}\text { Sig. } \\
(2- \\
\text { taile })\end{array}$ \\
\hline $\begin{array}{l}\text { Postest } \\
\text { Pretest }\end{array}$ & 39.960 & 4.128 & .826 & 48.402 & 24 & .000 \\
\hline
\end{tabular}

Berdasarkan tabel 4.4 di atas diketahui nilai $t_{\text {hitung }}$ adalah 48,40 dengan nilai $t_{\text {tabel }}$ yang diperoleh dari tabel $t$ test untuk jumlah sampel 30 siswa dan taraf titik kritis 5\% maka di ketahui nilai $t_{\text {tabel }}$ sebesar 2,07, maka diperoleh $t_{\text {hitung }}>t_{\text {tabel }}(48,40>2,07)$ yang artinya adalah menerima $\mathrm{H}_{\mathrm{a}}$ yaitu terdapat pengaruh model pembelajaran think pair share(TPS) terhadap kemampuan komunikasi matematika siswa kelas X SMA Melati Binjai Tahun Pelajaran 2019/ 2020.

\section{Temuan Penelitian}

Berdasarkan hasil penelitian di atas maka ditemukan beberapa hal secara umum yaitu:

1. Dari hasil pretest dan postest ditemukan nilai rata-rata pretest adalah 39,20 meningkat pada data postest menjadi 79,16 .

2. Kedua data (pretest dan postest) berasal dari penyebaran sampel yang berdistribusi normal, ditunjukkan dari keterangan nilai signifikansi (sig.) untuk pretest sebesar 0,190 dan postest sebesar 0,208, dimana kedua nilai siginifikan (sig.) keduanya lebih besar dari 0,05.

3. Berdasarkan hasil uji regresi linear sederhana diperoleh persamaan regresi yaitu $Y=47,88+0,79 X$

4. Konstanta (a) sebesar 47,88 menunjukkan bahwa ketika variable independent model pembelajaran think pair share (TPS) konstan, maka rata-rata kemampuan komunikasi matematika sebsar 47,88.

5. Koefisien regresi model pembelajaran think pair share (TPS) sebesar 0,79, menunjukkan bahwa setiap kenaikan 1 konstanta pada variabel model pembelajaran think pair share (TPS) akan meningkatkan kemampuan komunikasi matematika siswa sebesar 0,79 . 
6. Koefisien regresi bernilai positif menunjukkan bahwa semakin baik penerapan model pembelajaran think pair share (TPS, maka semakin baik pula kemampuan komunikasi matematika siswa.

7. Berdasarkan hasil pengujian hipotesis terlihat bahwa $t_{\text {hitung }}>t_{\text {tabel }}(48,40>2,07)$, artinya terdapat pengaruh model pembelajaran think pair share(TPS) terhadap kemampuan komunikasi matematika siswa kelas X SMA Melati Binjai Tahun Pelajaran 2019/ 2020.

\section{Pembahasan Hasil Penelitian}

Penelitian pengaruh model pembelajaran think pair share (TPS) ditinjau dari kemampuan komunikasi matematika siswa terdiri dari satu variabel bebas dan satu variabel terikat. Dalam penelitian ini, yang menjadi variabel bebas adalah model pembelajaran think pair share (TPS) sedangkan variabel terikatnya adalah kemampuan komunikasi matematika siswa. Dalam pelaksanaan penerapan model pembelajaran think pair share (TPS) selama penelitian pada pertemuan pertama mulanya aktivitas siswa untuk berfikir dan mendiskusikan hasil pemikirannya dengan teman dan juga memancing keberanian siswa untuk mengemukakan pendapatnya di depan kelas masih sedikit ragu-ragu namum pada pertemuan selanjutnya mereka sudah mulai terbiasa dengan model pembelajaran think pair share (TPS). Model pembelajaran think pair share (TPS) menekankan kepada siswa untuk bekerjasama dengan pasangannya dan saling membantu dalam memecahkan masalah bersama sehingga dapat mengembangkan kemampuan komunikasi matematikanya. Model pembelajaran think pair share (TPS) yang memiliki tiga tahap penting yakni thinking, pairing dan sharing, bisa diterapkan untuk membangun kemampuan kemunikasi matematika siswa menjadi lebih baik. Hal ini tampak dari peningkatan hasil nilai rata-rata dari 39,20 saat pretest meningkat menjadi 79,16 saat postest.

Dengan demikian, menggunakan tiga tahapan dalam model pembelajaran think pair share (TPS) memberikan peluang kepada siswa untuk mengembangkan kemampuan komunikasi matematika siswa. Dengan berkembangnya kemampuan komunikasi matematika siswa akan menghasilkan kemampuan siswa dalam menyelesaikan masalah terkait komunikasi matematika sehingga siswa akan tuntas dalam belajar matematika.

Berdasarkan uraian di atas dapat disimpulkan bahwa model pembelajaran think pair share (TPS) merupakan model pembelajaran yang dapat membuat siswa menjadi aktif dalam proses pembelajaran dikelompoknya sehingga dapat mengasah kemampuan komunikasi matematika siswa terhadap materi yang diajarkan. kemampuan komunikasi matematika siswa pada materi sistem persamaan linear tiga variabel (SPLTV) lebih spesifik ditunjukkan dari hasil perhitungan uji hipotesis dengan rumus t test diketahui nilai $t_{\text {hitung }}$ adalah 48,40 dengan nilai $\mathrm{t}_{\text {tabel }}$ yang diperoleh dari tabel $\mathrm{t}$ test untuk jumlah sampel 30 siswa dan taraf titik kritis 5\% maka di ketahui nilai $t_{\text {tabel }}$ sebesar 2,07, maka diperoleh $t_{\text {hitung }}>t_{\text {tabel }}(48,40>2,07)$ yang artinya terdapat pengaruh model pembelajaran think pair share(TPS) terhadap kemampuan komunikasi matematika siswa kelas X SMA Melati Binjai Tahun Pelajaran 2019/2020.

\section{KESIMPULAN DAN SARAN}

\section{A. Kesimpulan}

Berdasarkan uraian hasil penelitian mengenai model pembelajaran think pair share (TPS) berpengaruh terhadap kemampuan komunikasi matematika siswa kelas X SMA Melati Binjai Tahun Pelajaran 2019/ 2020. Secara spesifik dapat disimpulkan bahwa:

1. Rata-rata kemampuan komunikasi matematika siswa kelas X SMA Melati Binjai sebelum diterapkannya model pembelajaran think pair share (TPS) hanya sebesar 52,33.

2. Rata-rata kemampuan komunikasi matematika siswa kelas X SMA Melati Binjai setelah diterapkannya model pembelajaran think pair share (TPS) meningkat dari 52,33 menjadi 72,50. 


\section{B. Saran}

Berdasarkan hasil penelitian yang telah diuraikan, maka dapat diajukan beberapa saran sebagai berikut:

1. Bagi siswa, siswa harus aktif dalam proses pembelajaran dengan model pembelajaran think pair share (TPS) agar dapat meningkatkan kemampuan komunikasi matematika siswa serta dapat memberikan siswa pengalaman belajar yang baru, lebih bermakna dan menyenangkan.

2. Bagi guru, sebaiknya guru dapat menerapkan model pembelajaran think pair share (TPS) ataupun alternatif model pembelajaran lainnya yang dapat meningkatkan kemampuan komunikasi matematika siswa.

3. Bagi peneliti, terus berinovasi dalam melakukan proses pembelajaran untuk kedepannya serta terus menambah wawasan dalam bidang penulisan karya ilmiah, dan bagi peneliti selanjutnya dapat dijadikan sebagai bahan referensi maupun sebagai bahan kutipan untuk melakukan penelitian yang relevan dengan penelitian ini.

4. Bagi sekolah, sebaiknya sekolah memiliki bahan referensi dan kebijakan dalam melaksanakan proses pembelajaran untuk meningkatkan mutu atau kualitas pembelajaran di sekolah, terutama pada bidang studi matematika di sekolah.

\section{DAFTAR PUSTAKA}

\section{Badan Standar Nasional Pendidikan (BSNP).Panduan Penyusunan Kurikulum Tingkat Satuan Pendidikan Jenjang Pendidikan Dasar dan Menengah. (Jakarta: BSNP, 2006)}

Depdiknas.Undang-Undang Sistem Pendidikan Nasional (UUSPN) No. 20 Tahun 2003. (Jakarta : Depdiknas, 2009)

Fathurohman Pupuh. Strategi Belajar Megajar. (Bandung : PT Refika Aditama, 2007)
Hamdani.Stategi Belajar Mengajar. (Bandung : Pustaka Setia, 2011)

Nurjaman Adi. Meningkatkan Kemampuan Komunikasi Matematik Siswa Smp Melalui Model Pembelajaran Kooperatif Tipe Think Pair Share (TPS). Jurnal Didaktik Volume 9, Nomor 1, Tahun 2015 - ISSN 19785089

Rahman Abdur, dkk. Matematika Studi dan Pengajaran. (Jakarta : PT Gramedia, 2016)

Saragih Sehat. Peningkatan Kemampuan Komunikasi Matematis SMA/MA di Kecamatan Simapng Ulim Melalui Model Pembelajaran Kooperatif Tipe STAD.Jurnal Pendidikan dan Kebudayaan No. 2 (Vol. 19). 2013 